\title{
Relative importance of macrophyte leaves for nitrogen uptake from flood water in tidal salt marshes
}

\author{
Tjeerd J. Bouma*, Johan Stapel, Jenny van der Heiden, Bas Koutstaal, \\ Jos van Soelen, Lennart van IJzerloo
}

Netherlands Institute of Ecology (NIOO-CEMO), PO Box 140, 4400 AC Yerseke, The Netherlands

\begin{abstract}
Nitrogen limits plant growth in most salt marshes. As foliar N-uptake makes a significant contribution to the overall $\mathrm{N}$-requirements of submerged plant species such as (e.g.) seagrasses, we tested if foliar N-uptake was also significant in Spartina anglica Hubbard, a species that dominates the lowest, regularly flooded areas of salt marshes in the SW Netherlands. Foliar N-uptake was compared for plants from 2 estuaries with contrasting $\mathrm{N}$-loads in their water column. $\mathrm{N}$-uptake was quantified by (1) flooding detached leaves in test tubes, (2) spraying leaves still attached to the plants, and (3) flooding whole plants, with solutions containing either ${ }^{15} \mathrm{NO}_{3}{ }^{-}$or ${ }^{15} \mathrm{NH}_{4}{ }^{+}$. We found that detaching the leaves from the plant underestimated $\mathrm{NH}_{4}{ }^{+}$uptake by between 30 and $50 \%$. Higher salinity also reduced foliar N-uptake. Uptake rates were higher for $\mathrm{NH}_{4}{ }^{+}$than for $\mathrm{NO}_{3}{ }^{-}$, as has been found for many submerged and terrestrial angiosperms and marine algae. Methodology also had a major effect on the uptake rate, with flooding of intact plants yielding higher uptake rates than spraying attached leaves. However, in general, foliar $\mathrm{N}$-uptake rates were low at the $\mathrm{NO}_{3}{ }^{-}$and $\mathrm{NH}_{4}{ }^{+}$concentrations that are actually present in the tidal waters during the growth season, and may at most contribute to around $10 \%$ of the growth requirement. This percentage is much less than for seagrasses, but in line with data for some terrestrial systems. We conclude that in contrast to seagrasses, foliar N-uptake does not form a significant contribution to the overall N-requirements of $S$. anglica. This low $\mathrm{N}$-uptake capacity of the $S$. anglica leaves appears to be a consequence of adaptations to survive tidal flooding.
\end{abstract}

KEY WORDS: Foliar uptake $\cdot$ Nitrate $\cdot$ Ammonium $\cdot$ Tidal marsh $\cdot{ }^{15} \mathrm{~N}$ labelling

\section{INTRODUCTION}

Some aquatic macrophytes such as seagrasses obtain a significant proportion of their nutrient requirements by uptake through their leaves, since N- and P-uptake from the soil may be limited by diffusion or uptake characteristics of their roots (Stapel et al. 1996, Lee \& Dunton 1999). Foliar uptake can supply around 50\% of the overall N-requirement of Thalassia testudinum (Lee \& Dunton 1999) and T. hemprichii (Stapel et al. 1996), between 30 and $90 \%$ of the overall N-requirement of Zostera marina (Iizumi \& Hattori 1982, Short

*E-mail: bouma@cemo.nioo.knaw.nl
\& McRoy 1984, Pedersen \& Borum 1992, 1993) and, in extreme cases, the complete N-requirement of Phyllospadix torreyi (Terrados \& Williams 1997). In the case of nitrogen, foliar uptake by seagrasses is generally higher for $\mathrm{NH}_{4}^{+}$than for $\mathrm{NO}_{3}^{-}$(Touchette \& Burkholder 2000). In terrestrial plants, foliar uptake is often severely restricted by the outer wall of the epidermal cells (Marschner 1995). Nevertheless, application of foliar nutrients can be useful in horticulture (e.g. LeaCox \& Syvertsen 1995, Reickenberg \& Pritts 1996, Umar et al. 1999) and foliar N-uptake can constitute a significant component in the mineral nutrition cycle of some terrestrial ecosystems (Marschner 1995). For example, in the forestal ecosystems of Central Europe and Northern America, foliar uptake can comprise 
a large external $\mathrm{N}$-source (3 to $10 \mathrm{kgN} \mathrm{ha}^{-1} \mathrm{yr}^{-1}$ : Brumme et al. 1992), even though it generally only meets a small fraction of the overall N-requirement of the trees (2 to $8 \%$ : Boyce et al. 1996; up to $5 \%$ : Wilson \& Tiley 1998). Although leaching and the presence of epiphytic macroflora complicates interpretation of throughfall studies (Pearson \& Stewardt 1993), it is also evident in terrestrial systems that foliar $\mathrm{N}$-uptake is generally more efficient for $\mathrm{NH}_{4}{ }^{+}$than for $\mathrm{NO}_{3}{ }^{-}$(Wilson 1992, Peuke et al. 1998, Ignatova \& Dambrine 2000). In this study, we address the question as to the extent in which foliar uptake of nitrogen contributes to the nutrient demand of halophytic species that grow in the lowest areas of tidal salt marshes.

Nitrogen limits plant growth in most marshes (Valiela \& Teal 1974, Kiehl et al. 1997) so that foliar $\mathrm{N}$-uptake would be beneficial to marsh plants. Plants that grow in the lowest parts of a salt marsh are flooded daily, which may enable them to take up any nutrients that are available in the tidal water. In contrast to seagrasses, which are generally flooded most of the time and may obtain a significant proportion of their nutrients by foliar uptake, halophytic salt marsh species are only flooded briefly. This difference in habitat may require different physiological characteristics in the 2 groups of species. The harsh conditions (windy and salty) of the relatively open-marsh environment may require halophytic salt-marsh species to have a relatively impermeable cuticle to prevent excessive water loss and excessive leaching of (in)organic solutes through the leaves. Such cuticle could hinder Nuptake by the leaves. As for the roots, the strongly reduced anoxic soil conditions that characterize the most frequently flooded parts of marshes (Armstrong et al. 1985, Ewing et al. 1997) may, to a certain degree, hinder nutrient uptake. Species from the low marsh need root systems that allow sufficient oxygen transport to facilitate aerobic metabolism and detoxification of the rhizosphere (Armstrong et al. 1991). This would be expected to result in relatively high carbon expenditure, which might make $\mathrm{N}$-uptake by the leaves profitable from an efficiency perspective. To our knowledge, surprisingly little is known about the importance of foliar nutrient acquisition in salt-marsh ecosystems. Existing studies mainly focus on belowground fertilization (e.g. Patrick \& Delaune 1976, Broome et al. 1983), whereas studies that do examine fertilization at the soil surface (e.g. Mendelssohn 1979) or in the water column (e.g. Wright et al. 1996) do not quantify foliar uptake.

We quantified the uptake of ${ }^{15} \mathrm{NO}_{3}{ }^{-}$and ${ }^{15} \mathrm{NH}_{4}{ }^{+}$by the leaves of Spartina anglica Hubbard in an estuary with a high (i.e. Westernschelde) versus a low (i.e. Easternschelde) nitrogen concentration in the water column. In both estuaries, S. anglica dominates the low-marsh areas that are flooded twice a day. Hence, we hypothesized that the uptake kinetics of $S$. anglica leaves would enable a significant contribution of foliar uptake to the overall N-demand for growth. Because of the lack of a standard method for studying foliar uptake in salt marshes, we measured uptake by (1) flooding detached leaves in test tubes, (2) spraying leaves still attached to the plant, and (3) flooding whole plants. Whereas Method 1 is easily applicable to large numbers of detached leaf samples, Methods 2 and 3 represent realistic simulations of leaves following and during a flood period, respectively. We also studied the effect of salt concentration, as the locations in the Westernschelde and Easternschelde differ in salinity. In the Westernschelde, we performed additional measurements on detached leaves of Tiriglochin maritima L. from the low/middle marsh and Elymus pycnanthus (Godron) Melderis from the high marsh. As the habitats from these species are less regularly flooded than that of $S$. anglica, we expected these species to have fewer adaptations facilitating foliar $\mathrm{N}$-uptake.

\section{MATERIALS AND METHODS}

Study area. The study was carried out in the salt marsh east of Waarde (approx. 90 ha) in the Westernschelde (WS) estuary (SW Netherlands; $51^{\circ} 24^{\prime} \mathrm{N}, 4^{\circ} 06^{\prime} \mathrm{W}$ ) and the salt marsh of Rattekaai (approx. 135 ha) in the Easternschelde (ES) estuary (SW Netherlands; $51^{\circ} 27^{\prime} \mathrm{N}, 4^{\circ} 09^{\prime} \mathrm{E}$ ). The WS estuary is part of an extensive salt, brackish, and freshwater tidal system. The high population density and intense agrarian and industrial activity around the Schelde river (Belgium) and WS estuary (Netherlands) result in high loads of nutrients in the water column. $\mathrm{NO}_{3}{ }^{-}$and $\mathrm{NH}_{4}{ }^{+}$concentrations are highest outside the growth season, when water temperatures are lowest (Fig. 1). The salinity in the Waarde marsh fluctuates around 18.5. Since the construction of the Volkerak dam in 1969, the ES estuary lacks freshwater input from any river, so that it in fact has become a tidal bay. Accordingly, the nutrient input is relatively low and the salinity is nearly constant around 31. The difference in salinity between the WS and ES marshes has caused distinct differences in the vegetation. However, the species that we used in the present study are readily found at both sites: Spartina anglica Hubbard is the dominant species in the lowest parts of the marsh (2.0 m NAP; de Leeuw et al. 1994), Tiriglochin maritima L. is a species found at the low/middle parts of the marsh (2.25 m NAP; de Leeuw et al. 1994) and Elymus pycnanthus (Godron) Melderis is dominant in the highest areas of the marsh (2.5 m NAP; de Leeuw et al. 1994). Elevation is given in meters above the Dutch Ordnance Level (m NAP), which is similar to mean sea level. 
Fig. 1. Annual fluctuations in $\mathrm{NO}_{3}{ }^{-}$and $\mathrm{NH}_{4}{ }^{+}$concentrations of the water column near the Westernschelde (WS) salt marsh east of Waarde and the Easternschelde (ES) salt marsh near Rattekaai. $\mathrm{NO}_{3}{ }^{-}$and $\mathrm{NH}_{4}{ }^{+}$concentrations are highest outside the growth season, when water temperatures are lowest. In the WS the average $\mathrm{NO}_{3}{ }^{-}$and $\mathrm{NH}_{4}{ }^{+}$concentrations $\left(\mu \mathrm{mol} \mathrm{l}{ }^{-1}\right)$ were $242 \pm 17(\mathrm{n}=35)$ and $21 \pm 4.9(\mathrm{n}=$ $35)$ for the cold periods $\left(\mathrm{T}<15^{\circ} \mathrm{C}\right)$, and $156 \pm 11(\mathrm{n}=23)$ and $8.1 \pm 2.6(\mathrm{n}=23)$ for the warm periods $\left(\mathrm{T}>15^{\circ} \mathrm{C}\right)$, respectively. In the $\mathrm{ES}$, the average $\mathrm{NO}_{3}{ }^{-}$and $\mathrm{NH}_{4}^{+}$concentrations $\left(\mu \mathrm{mol} \mathrm{l} \mathrm{l}^{-1}\right)$ were 26.3 $\pm 0.6(\mathrm{n}=488)$ and $8.1+0.2(\mathrm{n}=484)$ for the cold periods $\left(\mathrm{T}<15^{\circ} \mathrm{C}\right)$, and $5.3 \pm 0.4$ $(\mathrm{n}=330)$ and $5.7 \pm 0.2(\mathrm{n}=343)$ for the warm periods $\left(\mathrm{T}>15^{\circ} \mathrm{C}\right)$
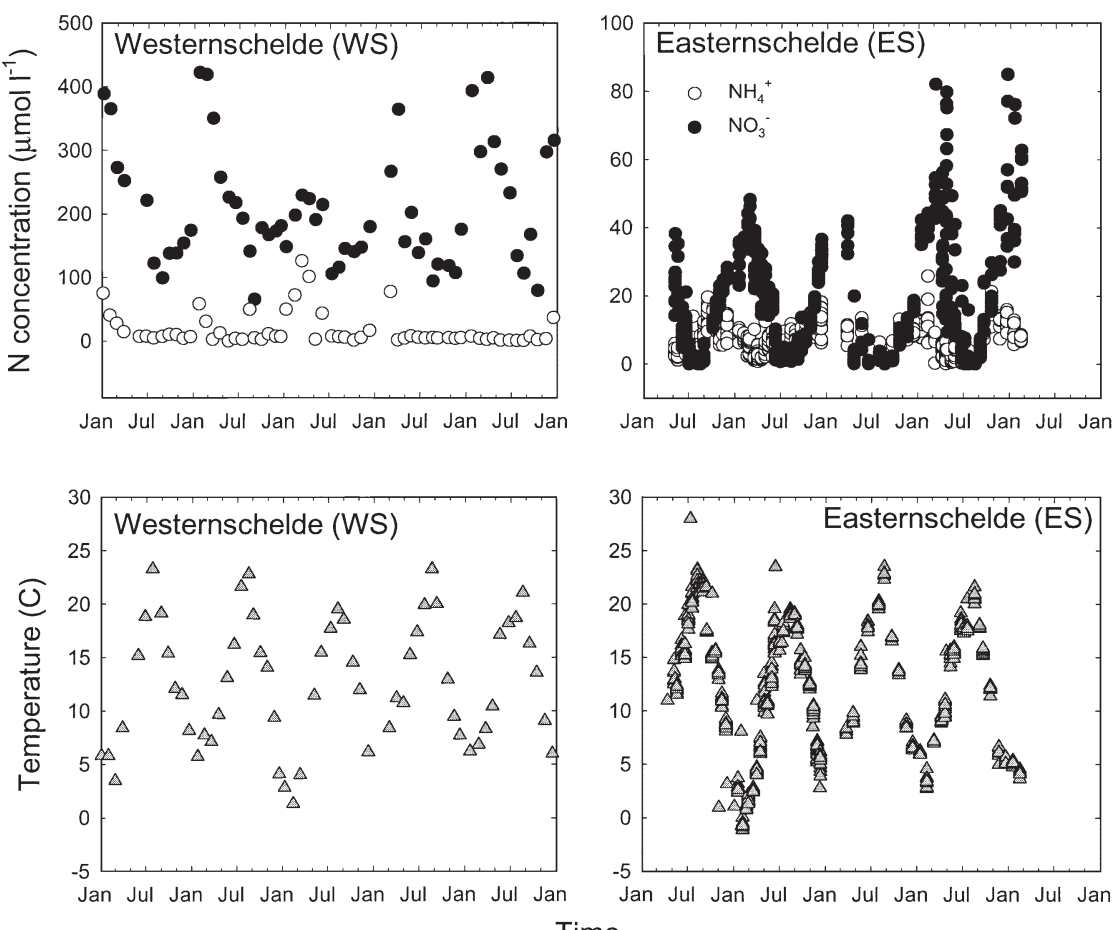

Uptake experiments. To our knowledge, little is known about the importance of foliar nutrient acquisition in salt-marsh ecosystems. Accordingly, a standard method for studying foliar uptake in salt marshes is lacking. In our study, we used 3 methods to quantify the uptake of ${ }^{15} \mathrm{NO}_{3}{ }^{-}$and ${ }^{15} \mathrm{NH}_{4}{ }^{+}$by the leaves: (1) flooding detached leaves in test tubes, (2) spraying leaves still attached to the plants and (3) flooding whole plants (Table 1). Method 1 was used as an easily applicable method on large numbers of detached leaf samples. Method 2 simulates leaves following a flood period, when the leaves are still covered with water droplets, and is easily applied to a large number of leaves that are still attached to the plant. Method 3 is a realistic simulation of conditions during flooding, when intact leaves may take up nutrients from the flood water; applying this method in the field is however difficult. In all experiments, the ${ }^{15} \mathrm{~N}$-labeled and the artificial seawater solutions used for rinsing the plants had the following composition $\left(\mathrm{g} \mathrm{l}^{-1}\right)$ to simulate local WS (13.2 NaCl, $1.75 \mathrm{Na}_{2} \mathrm{SO}_{4}, 4.77 \mathrm{MgCl}_{2} \cdot 6 \mathrm{H}_{2} \mathrm{O}$, $\left.0.30 \mathrm{KCl}, 0.88 \mathrm{CaCl}_{2} \cdot 2 \mathrm{H}_{2} \mathrm{O}\right)$ and ES (22.5 NaCl, $2.99 \mathrm{Na}_{2} \mathrm{SO}_{4}, 8.11 \mathrm{MgCl}_{2} \cdot 6 \mathrm{H}_{2} \mathrm{O}, 0.50 \mathrm{KCl}, 1.50 \mathrm{CaCl}_{2}$. $2 \mathrm{H}_{2} \mathrm{O}$ ) waters, respectively. To maximize the sensitivity of measuring uptake at low $\mathrm{N}$-concentrations, all solutions were fully labelled (i.e. the $\mathrm{N}$ in $\mathrm{NO}_{3}{ }^{-}$or $\mathrm{NH}_{4}{ }^{+}$ consisted of $98 \%{ }^{15} \mathrm{~N}$ ).

In Method 1, test tubes were filled with a solution of either ${ }^{15} \mathrm{NO}_{3}{ }^{-}$or ${ }^{15} \mathrm{H}_{4}{ }^{+}$. The solution in each tube was well mixed by aeration. We placed 3 to 5 of the youngest, freshly cut, full-grown leaves upside down in a test tube (height $160 \mathrm{~mm}$; diameter $13 \mathrm{~mm}$ ), taking care that the cut surface remained just above the solution. The leaves within a single tube were regarded as a single sample; replicates consisted of several independent tubes for each concentration. Incubations were in the field at ambient light and temperature. After $0.5 \mathrm{~h}$, the leaves were briefly rinsed in 3 succeeding beakers with unlabelled $\mathrm{NO}_{3}{ }^{-}$or $\mathrm{NH}_{4}{ }^{+}$solution, at a concentration (Table 1) similar to that used during the previous ${ }^{15} \mathrm{~N}$-uptake period. To determine the effect of salinity, some $\mathrm{N}$-concentrations were duplicated at the salinity of the other location (i.e. 'contrasting' salinity: Table 1).

To test the effect of detaching leaves, we compared the ${ }^{15} \mathrm{~N}$-uptake of detached versus attached leaves for Spartina anglica plants cultivated in a climate room. In contrast to the field situation, the leaves of these control plants had not been previously exposed to regular flooding (Control 1: Table 1).

In Method 2, individual leaves that were still attached to plants in the field were sprayed with either a ${ }^{15} \mathrm{NO}_{3}{ }^{-}$or a ${ }^{15} \mathrm{NH}_{4}{ }^{+}$solution, until the whole leaf was covered (concentrations listed in Table 1). Although the amount of solution applied could represent a limiting N-supply, it represents the maximum amount that can be applied in this manner. To obtain independent replicates, we used different individual plants for different sprayings. After $2 \mathrm{~h}$ incubation at ambient light and temperature, the leaves were harvested and briefly rinsed as described for Method 1. 
Table 1. Spartina anglica (Spa), Tiriglochin maritima (Tri) and Elymus pycnanthus (Ely). Overview of experiments on N-uptake by the leaves. Except for the experiment in the climate room, all measurements were in the field. Study areas WS and ES $=$ Westernschelde salt marsh east of Waarde and Easternschelde salt marsh near Rattekaai, respectively; local salinity in WS and ES = 18.5 and 31, respectively, 'contrasting' salinity was the salinity of the other location; soil trenching = plant collars filled with ${ }^{15} \mathrm{~N}$-solution without agar. Replicates column indicates number of test tubes (Expt 1), number of individually sprayed leaves, each on a separate plant (Expt 2), and number of flooded plants (Expt 3) per N-concentration and N-form

\begin{tabular}{|c|c|c|c|c|c|c|c|c|c|c|}
\hline $\begin{array}{l}\text { Expt } \\
\text { Species }\end{array}$ & $\begin{array}{l}\text { Study } \\
\text { area }\end{array}$ & Salinity & $\begin{array}{c}\text { Experimental design } \\
\text { (N-application + tissue type) }\end{array}$ & $\begin{array}{c}\text { Light } \\
\left(\mathrm{mmol} \mathrm{m}^{-2} \mathrm{~s}^{-1}\right)\end{array}$ & $\mathrm{T}\left({ }^{\circ} \mathrm{C}\right)$ & $\mathrm{N}$-form & $\begin{array}{l}\text { N-conc. } \\
(\mathrm{mM})\end{array}$ & $\begin{array}{l}\text { N-exp. } \\
\text { (h) }\end{array}$ & Repl. & Fig. \\
\hline \multicolumn{11}{|l|}{ Expt 1} \\
\hline \multirow[t]{2}{*}{ Ely } & WS & Local & Detached leaves in test tubes & $863 \pm 132$ & $17 \pm 0.6$ & $\mathrm{NO}_{3}^{-}$ & $\begin{array}{c}1,5,10,50 \\
100,500\end{array}$ & 0.5 & 4 & 3 \\
\hline & WS & Local & Detached leaves in test tubes & $863 \pm 132$ & $17 \pm 0.6$ & $\mathrm{NH}_{4}^{+}$ & $\begin{array}{c}1,5,10,50 \\
100,500\end{array}$ & 0.5 & 4 & 3 \\
\hline \multirow[t]{2}{*}{ Tri } & WS & Local & Detached leaves in test tubes & $863 \pm 132$ & $17 \pm 0.6$ & $\mathrm{NO}_{3}^{-}$ & $\begin{array}{c}1,5,10,50 \\
100,500\end{array}$ & 0.5 & 4 & 3 \\
\hline & WS & Local & Detached leaves in test tubes & $863 \pm 132$ & $17 \pm 0.6$ & $\mathrm{NH}_{4}{ }^{+}$ & $\begin{array}{c}1,5,10,50 \\
500\end{array}$ & 0.5 & 4 & 3 \\
\hline \multirow[t]{4}{*}{ Spa } & $\mathrm{WS}+\mathrm{ES}$ & Local & Detached leaves in test tubes & $863 \pm 132$ & $17 \pm 0.6$ & $\mathrm{NO}_{3}^{-}$ & $\begin{array}{c}1,5,10,50 \\
100,500\end{array}$ & 0.5 & 4 & 2 \\
\hline & $\mathrm{WS}+\mathrm{ES}$ & 'Contrasting' & Detached leaves in test tubes & $863 \pm 132$ & $17 \pm 0.6$ & $\mathrm{NO}_{3}^{-}$ & 10,100 & 0.5 & 4 & 4 \\
\hline & $\mathrm{WS}+\mathrm{ES}$ & Local & Detached leaves in test tubes & $863 \pm 132$ & $17 \pm 0.6$ & $\mathrm{NH}_{4}^{+}$ & $\begin{array}{c}1,5,10,50 \\
100,500\end{array}$ & 0.5 & 4 & 2 \\
\hline & $\mathrm{WS}+\mathrm{ES}$ & 'Contrasting' & Detached leaves in test tubes & $863 \pm 132$ & $17 \pm 0.6$ & $\mathrm{NH}_{4}^{+}$ & 10,100 & 0.5 & 4 & 4 \\
\hline \multicolumn{11}{|c|}{ Control 1} \\
\hline \multirow{4}{*}{ Spa } & Climate room & 0 & Detached leaves in test tubes & 350 & 20 & $\mathrm{NO}_{3}^{-}$ & 10,100 & 0.5 & 8 & 5 \\
\hline & Climate room & 0 & Detached leaves in test tubes & 350 & 20 & $\mathrm{NO}_{3}^{-}$ & 10,100 & 0.5 & 8 & 5 \\
\hline & Climate room & 0 & Detached leaves in test tubes & 350 & 20 & $\mathrm{NH}_{4}^{+}$ & 10,100 & 0.5 & 8 & 5 \\
\hline & Climate room & 0 & Detached leaves in test tubes & 350 & 20 & $\mathrm{NH}_{4}^{+}$ & 10,100 & 0.5 & 8 & 5 \\
\hline \multicolumn{11}{|l|}{ Expt 2} \\
\hline \multirow[t]{2}{*}{ Spa } & $\mathrm{WS}+\mathrm{ES}$ & Local & Spraying attached leaves & $815 \pm 54$ & $19 \pm 0.2$ & $\mathrm{NO}_{3}{ }^{-}$ & $1,5,10,50$ & 2 & 6 & 6 \\
\hline & $\mathrm{WS}+\mathrm{ES}$ & Local & Spraying attached leaves & $815 \pm 54$ & $19 \pm 0.2$ & $\mathrm{NH}_{4}^{+}$ & $1,5,10,50$ & 2 & 6 & 6 \\
\hline \multicolumn{11}{|l|}{ Expt 3} \\
\hline \multirow[t]{2}{*}{ Spa } & $\mathrm{WS}+\mathrm{ES}$ & Local & Flooding intact plants & $1007 \pm 89$ & $19 \pm 0.5$ & $\mathrm{NO}_{3}^{-}$ & $1,5,10,50$ & 1.5 & 6 & 7 \\
\hline & $\mathrm{WS}+\mathrm{ES}$ & Local & Flooding intact plants & $1007 \pm 89$ & $19 \pm 0.5$ & $\mathrm{NH}_{4}^{+}$ & $1,5,10,50$ & 1.5 & 6 & 7 \\
\hline \multicolumn{11}{|c|}{ Control 3} \\
\hline \multirow[t]{4}{*}{ Spa } & $\mathrm{WS}+\mathrm{ES}$ & Local & Soil trenching of intact plants & $1007 \pm 89$ & $19 \pm 0.5$ & $\mathrm{NO}_{3}^{-}$ & 5 & 1.5 & 2 & \\
\hline & $\mathrm{WS}+\mathrm{ES}$ & Local & Soil trenching of intact plants & $1007 \pm 89$ & $19 \pm 0.5$ & $\mathrm{NO}_{3}^{-}$ & 50 & 1.5 & 3 & \\
\hline & $\mathrm{WS}+\mathrm{ES}$ & Local & Soil trenching of intact plants & $1007 \pm 89$ & $19 \pm 0.5$ & $\mathrm{NH}_{4}^{+}$ & 5 & 1.5 & 2 & \\
\hline & $W S+E S$ & Local & Soil trenching of intact plants & $1007 \pm 89$ & $19 \pm 0.5$ & $\mathrm{NH}_{4}^{+}$ & 50 & 1.5 & 3 & \\
\hline
\end{tabular}

In Method 3, we put a small collar (height $160 \mathrm{~mm}$; diameter $160 \mathrm{~mm}$ ), around the base of individual plants in the field. Into these collars we poured agar solution $\left(15 \mathrm{~g} \mathrm{l}^{-1}\right)$ just above solidification temperature $\left(36^{\circ} \mathrm{C}\right)$ untill it reached approximately $4 \mathrm{~cm}$ in height. Immediately after pouring in the agar, we placed a tall transparent Plexiglas cylinder (height $450 \mathrm{~mm}$; diameter $100 \mathrm{~mm}$ ) inside each collar. After the agar had solidified, each Plexiglas cylinder was filled with an average of $2.9 \pm 0.02 \mathrm{l}(\mathrm{n}=94)$ of a ${ }^{15} \mathrm{NO}_{3}{ }^{-}$or a ${ }^{15} \mathrm{NH}_{4}{ }^{+}$ solution (concentrations listed in Table 1). To determine if leakage occurred, we measured the level of the solution in each Plexiglas cylinder directly after filling and just before harvesting. If the leakage exceeded $10 \%$ of the total volume, the plant sample was discarded (maximum leakage was $314 \mathrm{ml}$, with an average of $115 \pm 8 \mathrm{ml} ; \mathrm{n}=94$ ). The solution was well mixed by aeration. After $1.5 \mathrm{~h}$ incubation at ambient light and temperature, the tall cores and small collars were removed, and the plants were cut just above the agar, whereafter they were briefly rinsed as described for Method 1, except that we used 101 buckets instead of the small beakers. In the laboratory, the plants were separated into leaves, stems and (if present) flowering parts. To determine if leakage of ${ }^{15} \mathrm{~N}$-solution into the soil could have affected the ${ }^{15} \mathrm{~N}$-content of the leaves by uptake through the roots within the $1.5 \mathrm{~h}$ period, we filled a few small collars with $400 \mathrm{ml}{ }^{15} \mathrm{~N}$-solution, without agar (soil trenching; Control 3: Table 1).

In all experiments, samples were kept on ice during transport to the laboratory, where they were frozen and freeze-dried. After freeze-drying, the samples were analyzed for $\mathrm{C}, \mathrm{N}$ and ${ }^{15} \mathrm{~N}$-content using an elemental analyzer (NA-1500, Carbo Erba) coupled via a 
Finnigan con-flow II interface to an isotope-ratio mass spectrometer (Finnigan Delta S). N-uptake rates were calculated using the following equations:

$$
\begin{gathered}
\mathrm{N}_{\text {tot }}=(\% \mathrm{~N} / 100) \times \mathrm{DM} \times 10^{3} \\
{ }^{15} \mathrm{~N}_{\text {upt }}=\left(\left[\%{ }^{15} \mathrm{~N}_{\text {end }}-\%{ }^{15} \mathrm{~N}_{\text {start }}\right] / 100\right) \times \mathrm{N}_{\text {tot }} \times 10^{3} \\
V_{\text {upt }}={ }^{15} \mathrm{~N}_{\text {upt }} \times 10^{3} /\left(\mathrm{DM} \times t_{\text {exp }}\right)
\end{gathered}
$$

where $\mathrm{N}_{\text {tot }}=$ the total amount $(\mathrm{mg})$ of $\mathrm{N}$ in the tissue studied; $\% \mathrm{~N}=$ the $\mathrm{N}$-content as percentage of weight; $\mathrm{DM}=$ the dry mass $(\mathrm{g})$ of the leaves; ${ }^{15} \mathrm{~N}_{\text {upt }}=$ the amount of ${ }^{15} \mathrm{~N}(\mu \mathrm{g})$ taken up from the flood water; $\%{ }^{15} \mathrm{~N}_{\text {end }}=$ the ${ }^{15} \mathrm{~N}$-content as percentage of the weight in the plant tissue that was flooded with ${ }^{15} \mathrm{~N}$-solution; $\%{ }^{15} \mathrm{~N}_{\text {start }}=$ the ${ }^{15} \mathrm{~N}$-content as percentage of the weight in the same type of plant tissue from a nearby control plant that was not flooded with ${ }^{15} \mathrm{~N}$-solution, $V_{\text {upt }}=$ the $\mathrm{N}$-uptake rate from the flood water per unit dry leaf mass (ng [ $g$ dry mass $]^{-1} \mathrm{~h}^{-1}$ ), $t_{\exp }=$ the experimental uptake period (h). Our calculation method can yield small negative values for the $\mathrm{N}$-uptake rate if the difference between $\%{ }^{15} \mathrm{~N}_{\text {end }}$ and $\%{ }^{15} \mathrm{~N}_{\text {start }}$ is small compared to the natural variation in $\%{ }^{15} \mathrm{~N}$. Such small negative (and also small positive) uptake rates are of course artifacts, and indicate that uptake rates are negligible. We also calculated the relative growth rate (RGR) that could be maximally supported by N-uptake from the flood water $\left(\mathrm{RGR}_{\max } ; \mathrm{mg} \mathrm{g}^{-1} \mathrm{~d}^{-1}\right)$ :

$$
\mathrm{RGR}_{\max }=V_{\text {upt }} \times t_{\text {flood }} /\left(\mathrm{N}_{\text {con }} \times 10^{3}\right)
$$

where $\mathrm{N}_{\text {con }}=$ the $\mathrm{N}$-content $\left(\mathrm{mg} \mathrm{N} \mathrm{g}^{-1}\right)$ in the tissue studied, and $t_{\text {flood }}=$ the daily flood period $\left(\mathrm{h} \mathrm{d}^{-1}\right)$. Finally, we calculated the maximum percentage of the overall N-demand needed for a linear increase of plant biomass with time, which could be taken up by the shoot from the flood water $\left(U_{\% ;} \%\right)$ :

$U_{\%}=100 \times \sum\left(V_{\text {upt }} \times 10^{-6} \times \mathrm{DM}_{t} \times t_{\text {flood }}\right) / \sum\left(\mathrm{GR} \times \mathrm{N}_{\text {con }}\right)$

where $\sum$ indicates monthly integration intervals, $\mathrm{DM}_{t}$ is the dry plant biomass at time $t\left(\mathrm{~g} \mathrm{~m}^{-2}\right)$, and GR is the linear rate $\left(\mathrm{g} \mathrm{m}^{-2} \mathrm{~d}^{-1}\right)$ by which plant biomass increased.

Statistical analysis. Analysis of variance (ANOVA) was used to test for effects of salinity, detaching leaves, location, $\mathrm{N}$-concentration, $\mathrm{N}$-form and possible interactions, using STATISTICA software (StatSoft). It was noted that the variance was not homogeneous. Due to the negative values this could not be solved by logtransformation. As our experiment generally included 3 factors, the possibilities for using non-parametric tests were limited. Because of the simple experimental design and the straightforward results with clearly visible differences, we chose to restrict our statistical analysis to ANOVA even though the variance was not homogeneous. When the ANOVA revealed significant differences, we did a post-hoc analysis using Tukey's honestly significant difference test (5\% significance level). All independent variables, interactions, and $F$ and $\mathrm{p}$ values are summarized in Table 2. Regression analyses were performed with STATISTICA software (StatSoft) and $\mathrm{p}$ values, $\mathrm{R}^{2}$ values, and the number of observations are given in the legends of the relevant figures. For all experiments, the exact number of replicates is listed in Table 1.

\section{RESULTS}

The rate of N-uptake by the youngest, freshly cut, fullgrown leaves (Method 1) increased linearly with increasing $\mathrm{N}$-concentration in the incubation medium for Spartina anglica from both the WS and ES (Fig. 2), as well as for Elymus pycnanthus and Triglochin maritima (Fig. 3) from the WS (regression equations in the relevant figure legends). In $S$. anglica and E. pycnanthus, foliar $\mathrm{N}$-uptake was greatest when ${ }^{15} \mathrm{~N}$ was supplied as ${ }^{15} \mathrm{NH}_{4}{ }^{+}$ (Figs. 2 \& 3). Only in T. maritima was ${ }^{15} \mathrm{~N}$-uptake independent of the N-form (Fig. 3). Small negative (and small positive) values for the $\mathrm{N}$-uptake rate are artifacts of our calculation method (Eqs. 1 to 3) that occur when the difference between $\%{ }^{15} \mathrm{~N}_{\text {end }}$ and $\%{ }^{15} \mathrm{~N}_{\text {start }}$ (Eq. 2) is small compared to the natural variation in $\%{ }^{15} \mathrm{~N}(0.37265 \pm$ $0.00066[\mathrm{n}=10]$ in the WS vs $0.36973 \pm 0.00012[\mathrm{n}=10]$ in the ES). Such small negative and positive values indicate that the $\mathrm{N}$-uptake rate is negligible. Regeneration can be excluded, as we used fully labelled ${ }^{15} \mathrm{~N}$-solutions, whereas the internal pools of field-grown plants consist to more than $99 \%$ of ${ }^{14} \mathrm{~N}$. Exposing S. anglica leaves collected from the WS and the ES to both their local salinity and the salinity of each other revealed that a higher salinity reduced foliar N-uptake (Fig. 4, Table 2). This effect however was not evident when directly comparing the uptake rates of leaves collected in the WS (Salinity = 18.5) and ES (Salinity = 31), respectively (Fig. 2).

In all species, uptake rates were low (Figs. $2 \& 3$ ) at the $\mathrm{N}$-concentrations that are actually present in the column water during the growth season: i.e. $156 \pm 11 \mu \mathrm{mol} \mathrm{NO}{ }_{3}^{-}$ $\mathrm{l}^{-1}$ and $8.1 \pm 2.6 \mu \mathrm{mol} \mathrm{NH}{ }_{4}{ }^{+} \mathrm{l}^{-1}$ in the WS vs $5.3 \pm 0.4 \mu \mathrm{mol}$ $\mathrm{NO}_{3}{ }^{-} \mathrm{l}^{-1}$ and $5.7 \pm 0.2 \mu \mathrm{mol} \mathrm{NH}{ }_{4}^{+} \mathrm{l}^{-1}$ in the ES (Fig. 1). This suggests that $\mathrm{N}$-uptake by leaves is only of minor importance with respect to the N-requirements for plant growth, both for the frequently flooded Spartina anglica plants and the occasionally flooded Triglochin maritima and Elymus pycnanthus plants. However, a control experiment with climate-room-grown $S$. anglica plants indicated that foliar $\mathrm{N}$-uptake may be underestimated by 30 to $50 \%$ in leaves detached from the shoot (Fig. 5, Table 2). To exclude artifacts due to leaf-excision, we repeated our experiments on intact plants by spraying the leaves (Method 2) or flooding whole plants (Method 3). 
Table 2. Spartina anglica. Results of analysis of variance (ANOVA) of data in Figs. 4-7. We tested the effect of leaf detachment (Control 1: Table 1) only for $\mathrm{NH}_{4}{ }^{+}$, as the uptake of $\mathrm{NO}_{3}{ }^{-}$was 0 (Fig. 5). CR: climate room. Independent variables are underlined; ${ }^{*, a, b, c}$ significant differences

\begin{tabular}{|c|c|c|c|c|c|c|c|}
\hline \multirow{2}{*}{\multicolumn{2}{|c|}{$\begin{array}{l}\text { Expt } \\
\text { Independent } \\
\text { variables }\end{array}$}} & \multirow[t]{2}{*}{$F$} & \multirow[t]{2}{*}{$\mathrm{p}$} & \multicolumn{4}{|c|}{ - N-uptake rates $\left(\mathrm{ng} \mathrm{g}^{-1} \mathrm{~h}^{-1}\right)$} \\
\hline & & & & & & & \\
\hline 1: N-form & 1,24 & 13.2 & $0.001^{*}$ & $\frac{\mathrm{NO}_{3}^{-}}{-25^{\mathrm{a}}}$ & $\frac{\mathrm{NH}_{4}^{+}}{711^{\mathrm{b}}}$ & & \\
\hline 2: N-conc. & 1,24 & 5.3 & $0.031^{*}$ & $\frac{10 \mu \mathrm{M}}{111^{\mathrm{a}}}$ & $\frac{100 \mu \mathrm{M}}{575^{\mathrm{b}}}$ & & \\
\hline 3: salinity & 1,24 & 5.3 & $0.031^{*}$ & $\frac{18.5 \mathrm{ppt}}{575^{\mathrm{b}}}$ & $\frac{31 \mathrm{ppt}}{111^{\mathrm{a}}}$ & & \\
\hline $1 \times 2$ & 1,24 & 2.8 & 0.108 & & & & \\
\hline $1 \times 3$ & 1,24 & 5.3 & $0.031^{*}$ & $\frac{\mathrm{NO}_{3}{ }^{-}-18.5 \mathrm{ppt}}{-24^{\mathrm{a}}}$ & $\frac{\mathrm{NO}_{3}{ }^{-}-31 \mathrm{ppt}}{-25^{\mathrm{a}}}$ & $\frac{\mathrm{NH}_{4}{ }^{+}-18.5 \mathrm{ppt}}{1174^{\mathrm{b}}}$ & $\frac{\mathrm{NH}_{4}{ }^{+}-31 \mathrm{ppt}}{247^{\mathrm{a}}}$ \\
\hline $\begin{array}{l}2 \times 3 \\
1 \times 2 \times 3\end{array}$ & $\begin{array}{l}1,24 \\
1,24\end{array}$ & $\begin{array}{l}6.8 \\
3.9\end{array}$ & $\begin{array}{l}0.015^{*} \\
0.060\end{array}$ & $\frac{10 \mu \mathrm{M}-18.5 \mathrm{ppt}}{79^{\mathrm{a}}}$ & $\frac{10 \mu \mathrm{M}-31 \mathrm{ppt}}{143^{\mathrm{a}}}$ & $\frac{100 \mu \mathrm{M}-18.5 \mathrm{ppt}}{1071^{\mathrm{b}}}$ & $\frac{100 \mu \mathrm{M}-31 \mathrm{ppt}}{79^{\mathrm{a}}}$ \\
\hline Salinity, ES (Fig. & & & & $\mathrm{NO}_{3}^{-}$ & $\mathrm{NH}_{4}^{+}$ & & \\
\hline 1: N-form & 1,24 & 67.7 & $0^{*}$ & $77^{\mathrm{a}}$ & $413^{b}$ & & \\
\hline 2: N-conc. & 1,24 & 109.6 & $0^{*}$ & $\frac{10 \mu \mathrm{M}}{32^{\mathrm{a}}}$ & $\frac{100 \mu \mathrm{M}}{458^{\mathrm{b}}}$ & & \\
\hline 3: salinity & 1,24 & 30.9 & $0^{*}$ & $\frac{18.5 \mathrm{ppt}}{358^{\mathrm{b}}}$ & $\frac{31 \mathrm{ppt}}{132^{\mathrm{a}}}$ & & \\
\hline $\begin{array}{l}1 \times 2 \\
1 \times 3 \\
2 \times 3 \\
1 \times 2 \times 3\end{array}$ & $\begin{array}{l}1,24 \\
1,24 \\
1,24 \\
1,24\end{array}$ & $\begin{array}{l}38.8 \\
0.9 \\
1.8 \\
0.7\end{array}$ & $\begin{array}{c}0^{*} \\
0.350 \\
0.190 \\
0.421\end{array}$ & $\frac{10 \mu \mathrm{M} \mathrm{NO}_{3}^{-}}{-9.1^{\mathrm{a}}}$ & $\frac{100 \mu \mathrm{M} \mathrm{NO}_{3}^{-}}{164^{\mathrm{b}}}$ & $\frac{10 \mu \mathrm{M} \mathrm{NH}_{4}^{+}}{72^{\mathrm{ab}}}$ & $\frac{100 \mu \mathrm{M} \mathrm{NH}_{4}{ }^{+}}{753^{\mathrm{c}}}$ \\
\hline Leaf detachment & CR (N-forn & $=\mathrm{NH}_{4}{ }^{+}$ & Fig. 5) & $10 \mu \mathrm{M} \mathrm{NH}_{4}^{+}$ & $100 \mathrm{\mu M} \mathrm{NH}_{4}^{+}$ & & \\
\hline 1: N-conc. & 1,28 & 13.5 & $9.9 \mathrm{E}-04^{*}$ & $\begin{array}{c}1092^{\mathrm{a}} \\
\text { Attached }\end{array}$ & $\begin{array}{c}2163^{\mathrm{b}} \\
\text { Detached }\end{array}$ & & \\
\hline $\begin{array}{l}2: \text { tissue } \\
1 \times 2\end{array}$ & $\begin{array}{l}1,28 \\
1,28\end{array}$ & $\begin{array}{l}6.5 \\
0.1\end{array}$ & $\begin{array}{l}0.017^{*} \\
0.719\end{array}$ & $1998^{b}$ & $1257^{\mathrm{a}}$ & & \\
\hline Spraying, WS + & S (Fig. 6) & & & WS & ES & & \\
\hline $\begin{array}{l}\text { 1: location } \\
\text { 2: N-form } \\
3: \text { N-conc. } \\
1 \times 2 \\
1 \times 3 \\
2 \times 3\end{array}$ & $\begin{array}{l}1,79 \\
1,79 \\
3,79 \\
1,79 \\
3,79 \\
3,79\end{array}$ & $\begin{array}{l}12.4 \\
0.0 \\
1,4 \\
0.1 \\
0.0 \\
0.7\end{array}$ & $\begin{array}{l}0.001 \\
0.953^{*} \\
0.263 \\
0.769 \\
0.995 \\
0.543\end{array}$ & $20^{\mathrm{a}}$ & $82^{\mathrm{b}}$ & & \\
\hline Flooding, WS + & $S$ leaves $(F$ & .7) & & WS & ES & & \\
\hline 1: location & 1,76 & 26.6 & $0^{*}$ & $872^{\mathrm{a}}$ & $3953^{b}$ & & \\
\hline 2: N-form & 1,76 & 46.9 & $0^{*}$ & $\frac{\mathrm{NO}_{3}^{-}}{368^{\mathrm{a}}}$ & $\frac{\mathrm{NH}_{4}^{+}}{4458^{\mathrm{b}}}$ & & \\
\hline $\begin{array}{l}3: \mathrm{N} \text {-conc. } \\
1 \times 2 \\
1 \times 3 \\
2 \times 3 \\
1 \times 2 \times 3\end{array}$ & $\begin{array}{l}3,76 \\
1,76 \\
3,76 \\
3,76 \\
3,76\end{array}$ & $\begin{array}{l}10.0 \\
18.2 \\
4.5 \\
8.2 \\
3.5\end{array}$ & $\begin{array}{c}0^{*} \\
0^{*} \\
0.006^{*} \\
0^{*} \\
0.019^{*}\end{array}$ & $\frac{1 \mu \mathrm{M}}{389^{\mathrm{a}}}$ & $\frac{5 \mu \mathrm{M}}{1227^{\mathrm{a}}}$ & $\frac{10 \mu \mathrm{M}}{3659^{\mathrm{b}}}$ & $\frac{50 \mu \mathrm{M}}{4375^{\mathrm{b}}}$ \\
\hline Flooding, WS + & ES Stem (Fi & .7) & & WS & ES & & \\
\hline 1: location & 1,77 & 5.8 & $0.018^{*}$ & $909^{\mathrm{a}}$ & $1652^{\mathrm{b}}$ & & \\
\hline 2: N-form & 1,77 & 45.9 & $0^{*}$ & $\frac{\mathrm{NO}_{3}^{-}}{235^{\mathrm{a}}}$ & $\frac{\mathrm{NH}_{4}^{+}}{2325^{\mathrm{b}}}$ & & \\
\hline & & & & $1 \mu \mathrm{M}$ & $5 \mu \mathrm{M}$ & $10 \mu \mathrm{M}$ & $50 \mu \mathrm{M}$ \\
\hline 3: N-conc. & 3,77 & 9.6 & $0^{*}$ & $\frac{1 \mu v}{155^{\mathrm{a}}}$ & $829^{\mathrm{ab}}$ & $1893^{\mathrm{bc}}$ & $2245^{\mathrm{c}}$ \\
\hline $1 \times 2$ & 1,77 & 2.7 & 0.102 & & & & \\
\hline $1 \times 3$ & 3,77 & 1.0 & 0.382 & & & & \\
\hline $2 \times 3$ & 3,77 & 8.1 & $0^{*}$ & & & & \\
\hline $1 \times 2 \times 3$ & 3,77 & 0.6 & 0.603 & & & & \\
\hline
\end{tabular}




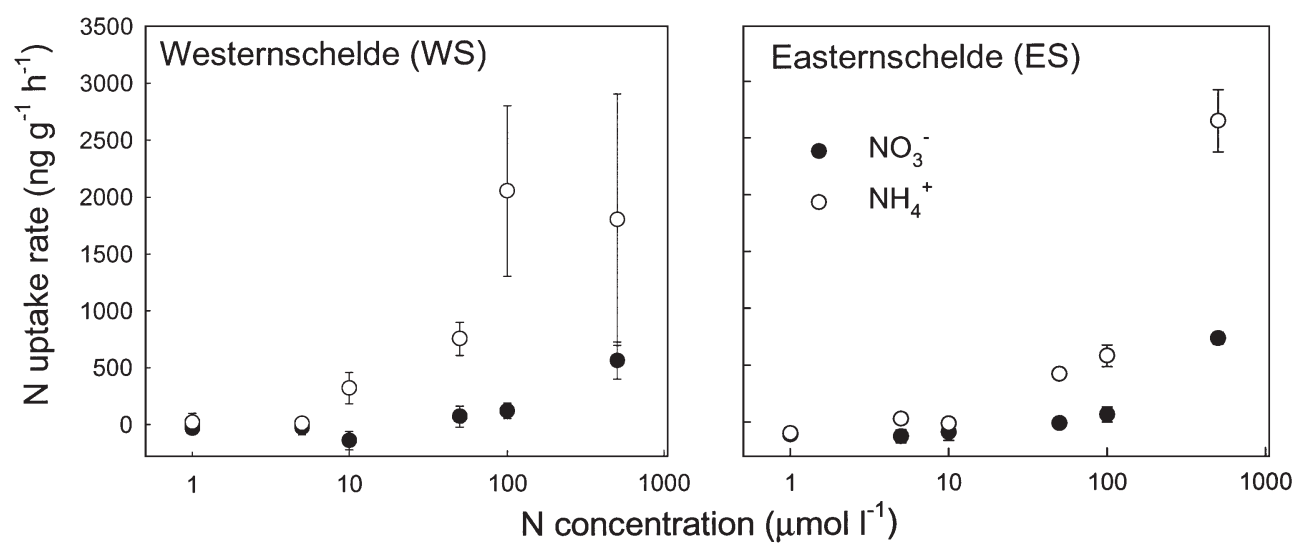

Fig. 2. Spartina anglica. Effects of $\mathrm{N}$-concentration $\left(\mathrm{C}_{i} \mu \mathrm{mol} \mathrm{l}^{-1}\right)$ on $\mathrm{NO}_{3}{ }^{-}$and $\mathrm{NH}_{4}{ }^{+}$uptake rates $\left(V_{\text {upti }} \mathrm{ng}[\mathrm{g} \text { dry mass }]^{-1} \mathrm{~h}^{-1}\right)$ of detached leaves from plants growing in the WS vs plants growing in the ES. We ${ }^{15} \mathrm{~N}$-labeled the leaves by placing them upside down in a test tube. The linear regression equations for $\mathrm{NO}_{3}{ }^{-}$and $\mathrm{NH}_{4}{ }^{+}$uptake rates by plants from the WS were $V_{\text {upt }}=1.0793 \mathrm{C}_{i}$ $\mathrm{R}^{2}=0.5908, \mathrm{p}=7.18 \times 10^{-6}(\mathrm{n}=24)$ and $V_{\text {upt }}=4.325 \mathrm{C}_{i} \mathrm{R}^{2}=0.0979, \mathrm{p}=0.1278(\mathrm{n}=24)$, respectively. The linear regression equations for $\mathrm{NO}_{3}{ }^{-}$and $\mathrm{NH}_{4}{ }^{+}$uptake rates by plants from the ES were $V_{\text {upt }}=5.3195 \mathrm{C}_{i} \mathrm{R}^{2}=0.9457, \mathrm{p}=4.44 \times 10^{-16}$ (n $\left.=24\right)$ and $V_{\text {upt }}=$ $1.4005 C_{;} R^{2}=0.8209, p=4.65 \times 10^{-10}(n=24)$, respectively. Linear regression lines are not shown because of the log-transformed $x$-axes

Spraying the leaves with ${ }^{15} \mathrm{NO}_{3}{ }^{-}$and ${ }^{15} \mathrm{NH}_{4}{ }^{+}$again resulted in low N-uptake rates (Fig. 6). This is probably due to the aggregation of the sprayed solution in droplets, which results in a minimal contact surface between the leaf and ${ }^{15} \mathrm{~N}$-labeled solution. Such problem does not exist when intact plants are flooded with a well-stirred solution that thus yields a more accurate estimate of the ${ }^{15} \mathrm{~N}$-uptake rates. Accordingly, we found much higher uptake rates for such flooded plants (Fig. 7). The absence of ${ }^{15} \mathrm{~N}$ in shoots from the plants that received the soil trenching treatment with ${ }^{15} \mathrm{~N}$-solution (data not shown) excludes the possibility that such higher uptake rates could in part be due to uptake by the roots.

To quantify the potential importance of N-uptake by the shoots for plant growth we calculated Eq. (4) the maximum relative growth rate that could be achieved under the assumptions that (1) flood water was the only $\mathrm{N}$-source and (2) the total shoots would on average be fully submerged for $2.4 \mathrm{~h} \mathrm{~d}^{-1}$. The $2.4 \mathrm{~h} \mathrm{~d}^{-1}$ period was based on the fact that the lowest Spartina anglica plants that grow around $2.0 \mathrm{~m}$ above the Dutch Ordnance Level (m NAP) are flooded by approx. $25 \mathrm{~cm}$ water $10 \%$ of the time (Fig. 8). Our calculation showed

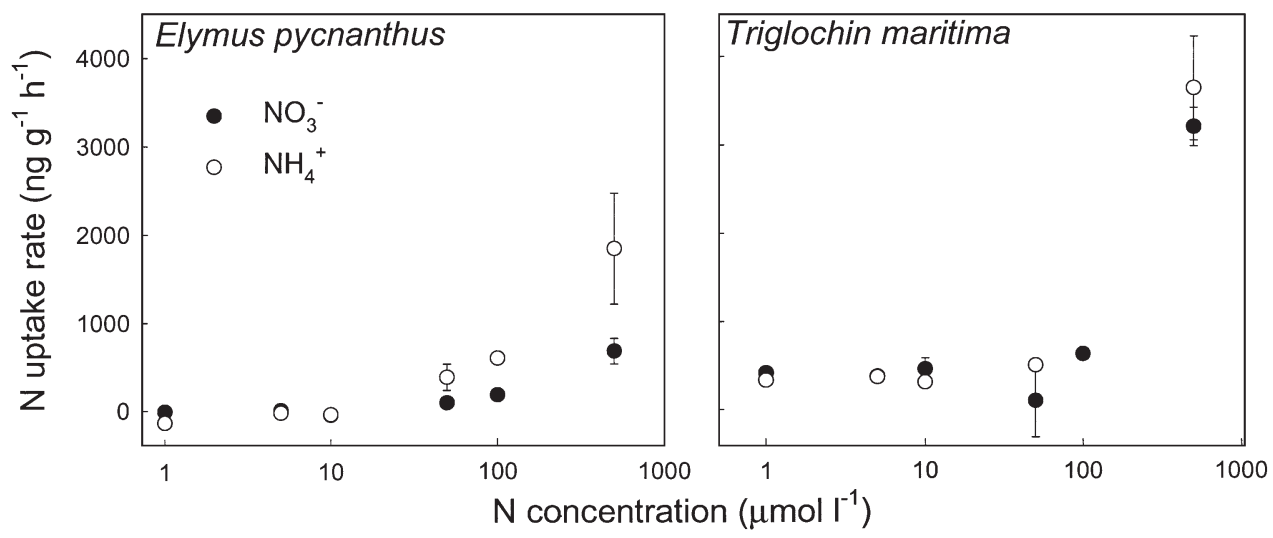

Fig. 3. Elymus pycnanthus and Triglochin maritima. Effects of $\mathrm{N}$-form and N-concentration $\left(\mathrm{C}_{i} \mu \mathrm{mol} \mathrm{l}^{-1}\right)$ on uptake rates $\left(V_{\text {upti }}\right.$ ng [g dry mass] ${ }^{-1} \mathrm{~h}^{-1}$ ) of detached leaves of plants sampled in the WS. The linear regression equations for $\mathrm{NO}_{3}^{-}$and $\mathrm{NH}_{4}{ }^{+}$uptake rates by $E$. pycnanthus were $V_{\text {upt }}=1.3436 \mathrm{C}_{;} \mathrm{R}^{2}=0.8066, \mathrm{p}=1.13 \times 10^{-9}(\mathrm{n}=24)$ and $V_{\text {upt }}=3.7681 \mathrm{C}_{;} \mathrm{R}^{2}=0.6574, \mathrm{p}=8.89 \times 10^{-7}$ $(\mathrm{n}=24)$, respectively. The linear regression equations for $\mathrm{NO}_{3}{ }^{-}$and $\mathrm{NH}_{4}{ }^{+}$uptake rates by $T$. maritima, were $V_{\text {upt }}=6.3708 \mathrm{C}_{i} \mathrm{R}^{2}=$ $0.8401, \mathrm{p}=8.12 \times 10^{-10}(\mathrm{n}=22)$ and $V_{\text {upt }}=7.3075 \mathrm{C}_{;} \mathrm{R}^{2}=0.8598, \mathrm{p}=1.51 \times 10^{-9}(\mathrm{n}=20)$, respectively. Linear regression lines are not shown because of the log-transformed $x$-axes 


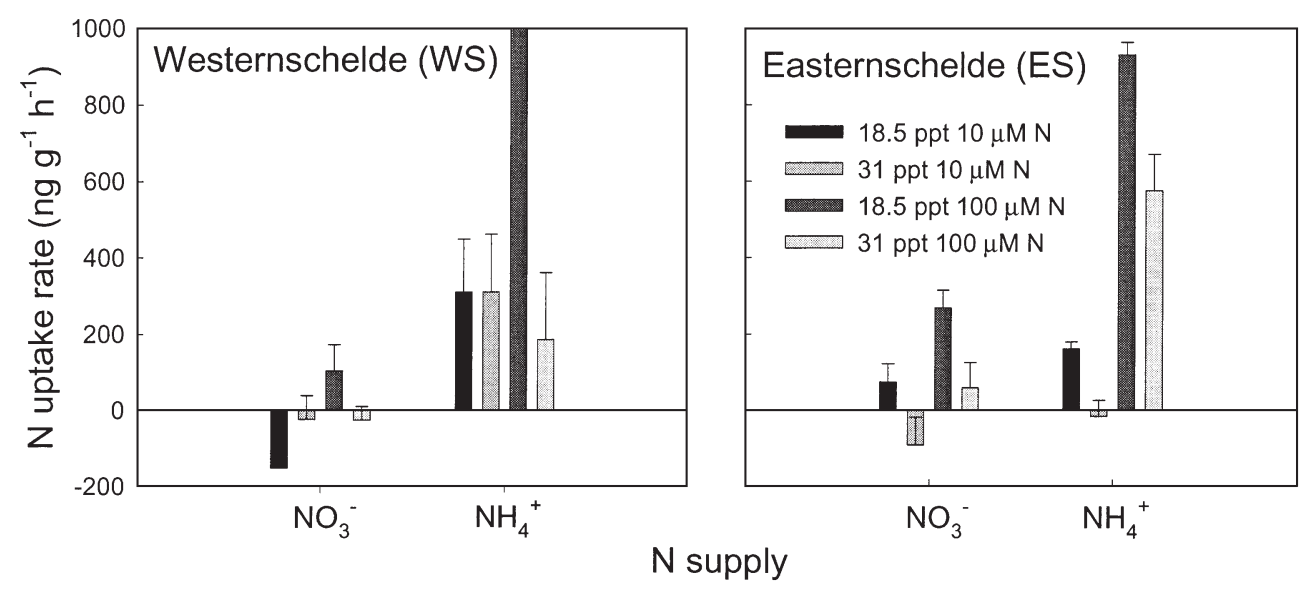

Fig. 4. Spartina anglica. Effects of salinity and N-concentration $\left(\mu \mathrm{mol} l^{-1}\right)$ on uptake rates $\left(\mathrm{ng}\left[\mathrm{g} \operatorname{dry} \mathrm{mass}^{-1} \mathrm{~h}^{-1}\right) \mathrm{of} \mathrm{NO}_{3}^{-}\right.$and $\mathrm{NH}_{4}{ }^{+}$ by detached leaves sampled from plants growing in the WS vs plants growing in the ES

that N-uptake by the shoots could only support a very low relative growth rate, even when we used the highest ${ }^{15} \mathrm{~N}$-uptake rates obtained for intact plants (Table 3). Since exponential growth mainly occurs at the early seedling growth stage we also calculated Eq. (5) the potential contribution of N-uptake by the shoots as a percentage of the $\mathrm{N}$-requirements needed for the approximately linear increase in biomass that occurs from May to September. We maintained our assumption that the total shoots would on average be fully submerged for $2.4 \mathrm{~h} \mathrm{~d}^{-1}$. In addition, we assumed a leaves/stem-ratio of 0.91 over the whole growth period (average for $225 \mathrm{~S}$. anglica plots harvested in September 1999). Our calculations indicated that vegetation with a relatively high biomass per $\mathrm{m}^{2}$, as would be present later in the growth season, could receive a substantial $\mathrm{NH}_{4}{ }^{+}$-supply from the shoots $(30 \%$ max.: Table 4), provided that (1) $\mathrm{NH}_{4}{ }^{+}$concentrations and
(2) flood frequency were sufficiently high. The reason is that during linear growth, new biomass is constantly being produced by a continuously increasing standing biomass (i.e. the RGR decreases over time). However, during the periods when the standing biomass is highest, the $\mathrm{NH}_{4}{ }^{+}$concentrations in the flood water are generally very low (average of ca. $5 \mu \mathrm{M}$ : Fig. 1), thus enabling only a much smaller contribution of N-uptake by the shoots (10\% max.: Table 4$)$. In addition, complete flooding for $2.4 \mathrm{~h} \mathrm{~d}^{-1}$ becomes less realistic when plants grow taller (Fig. 8), as is the case towards the end of the growth season. Shorter periods of complete flooding proportionally decrease the relative contribution of N-uptake by the shoots to the N-requirements for growth. Hence, we conclude that N-uptake by leaves makes only a minor contribution (up to around $10 \%$ ) to the N-requirements for plant growth in the frequently flooded $S$. anglica plants in the low marsh.
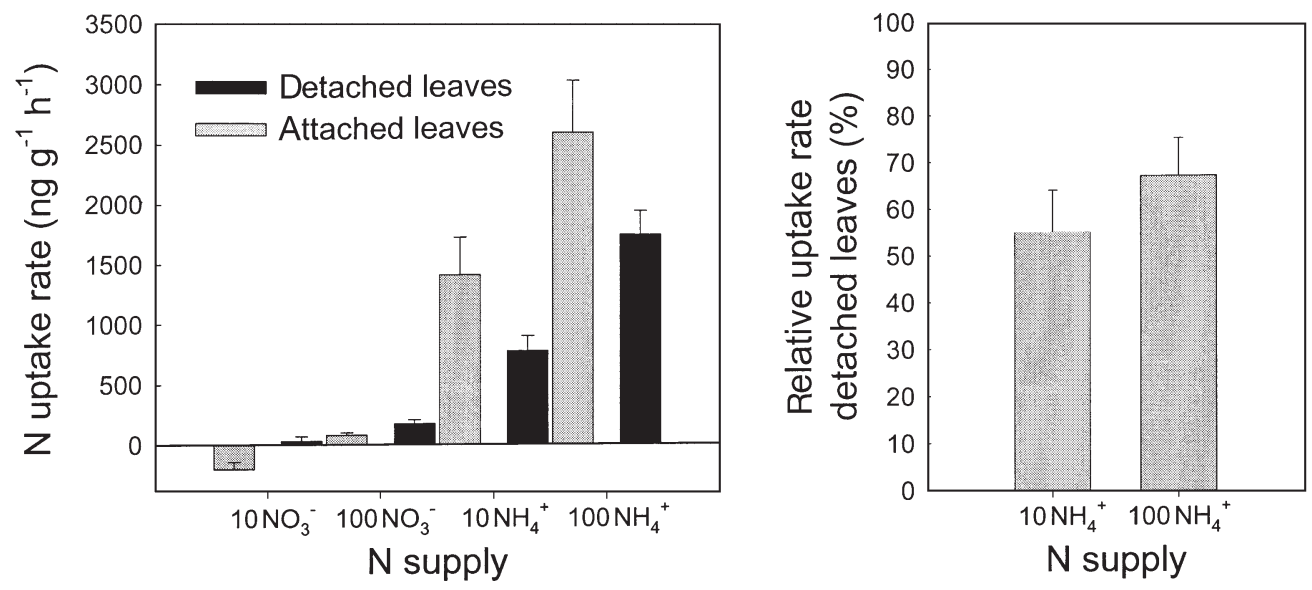

Fig. 5. Spartina anglica. Effects of leaf detachment on uptake rates (ng $[\mathrm{g} \text { dry mass }]^{-1} \mathrm{~h}^{-1}$ ) of $\mathrm{NO}_{3}{ }^{-}$and $\mathrm{NH}_{4}{ }^{+}$by leaves from plants cultivated in a climate room. $\mathrm{NO}_{3}{ }^{-}$and $\mathrm{NH}_{4}{ }^{+}$were supplied at concentrations of 10 and $100 \mu \mathrm{mol} \mathrm{l^{-1 }}$. For the $\mathrm{NH}_{4}{ }^{+}$treatments the uptake rate of the detached leaves is expressed as a percentage of that of the attached leaves 


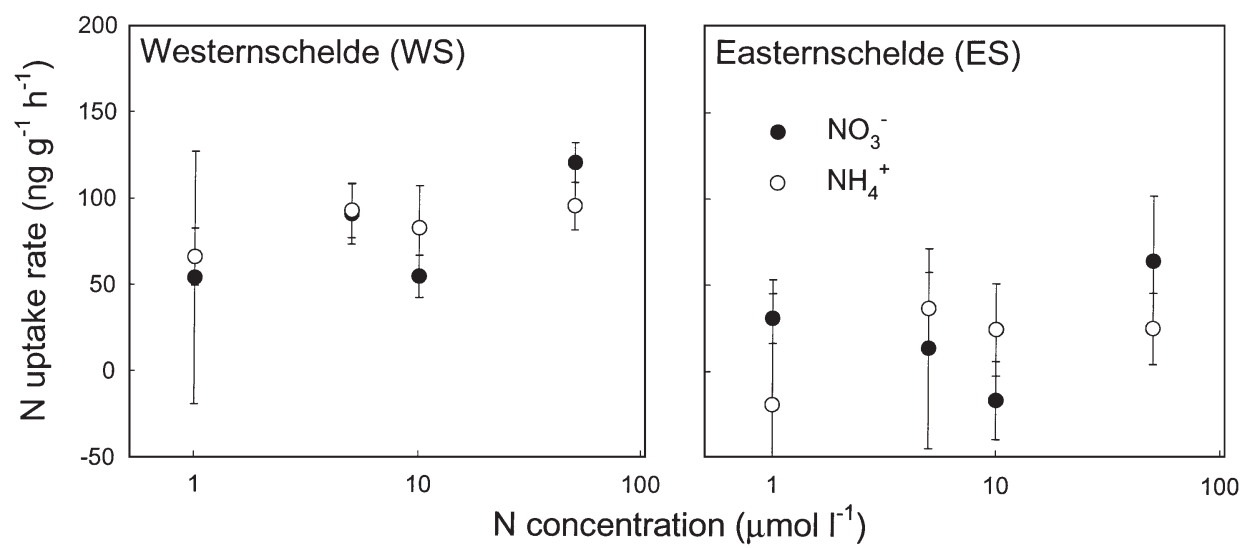

Fig. 6. Spartina anglica. Effects of $\mathrm{N}$-concentration $\left(\mu \mathrm{mol} \mathrm{l}^{-1}\right)$ on uptake rates $\left(\mathrm{ng}[\mathrm{g} \text { dry mass }]^{-1} \mathrm{~h}^{-1}\right)$ of $\mathrm{NO}_{3}{ }^{-}$and $\mathrm{NH}_{4}{ }^{+}$by attached leaves from plants growing in the WS vs plants growing in the ES. ${ }^{15} \mathrm{~N}$-labeling was provided to the plants by spraying the attached leaves

\section{DISCUSSION}

The present results clearly show that (1) selection of a proper application method (i.e. flooding intact plants) is essential for quantifying the $\mathrm{N}$-uptake rate by leaves of salt-marsh species, and that (2) N-uptake by the shoots makes only a small contribution to the
$\mathrm{N}$-requirements for growth in the salt-marsh species we studied. Under favorable conditions, N-uptake by the shoots could only cover the $\mathrm{N}$-demand required to support a relative growth rate (RGR) of around $2.5 \mathrm{mg}$ $\mathrm{g}^{-1} \mathrm{~d}^{-1}$ (Table 3) whereas most slow-growing species can easily reach an RGR of around $100 \mathrm{mg} \mathrm{g}^{-1} \mathrm{~d}^{-1}$ (Poorter \& Remkes 1990, Poorter et al. 1991). In vege-

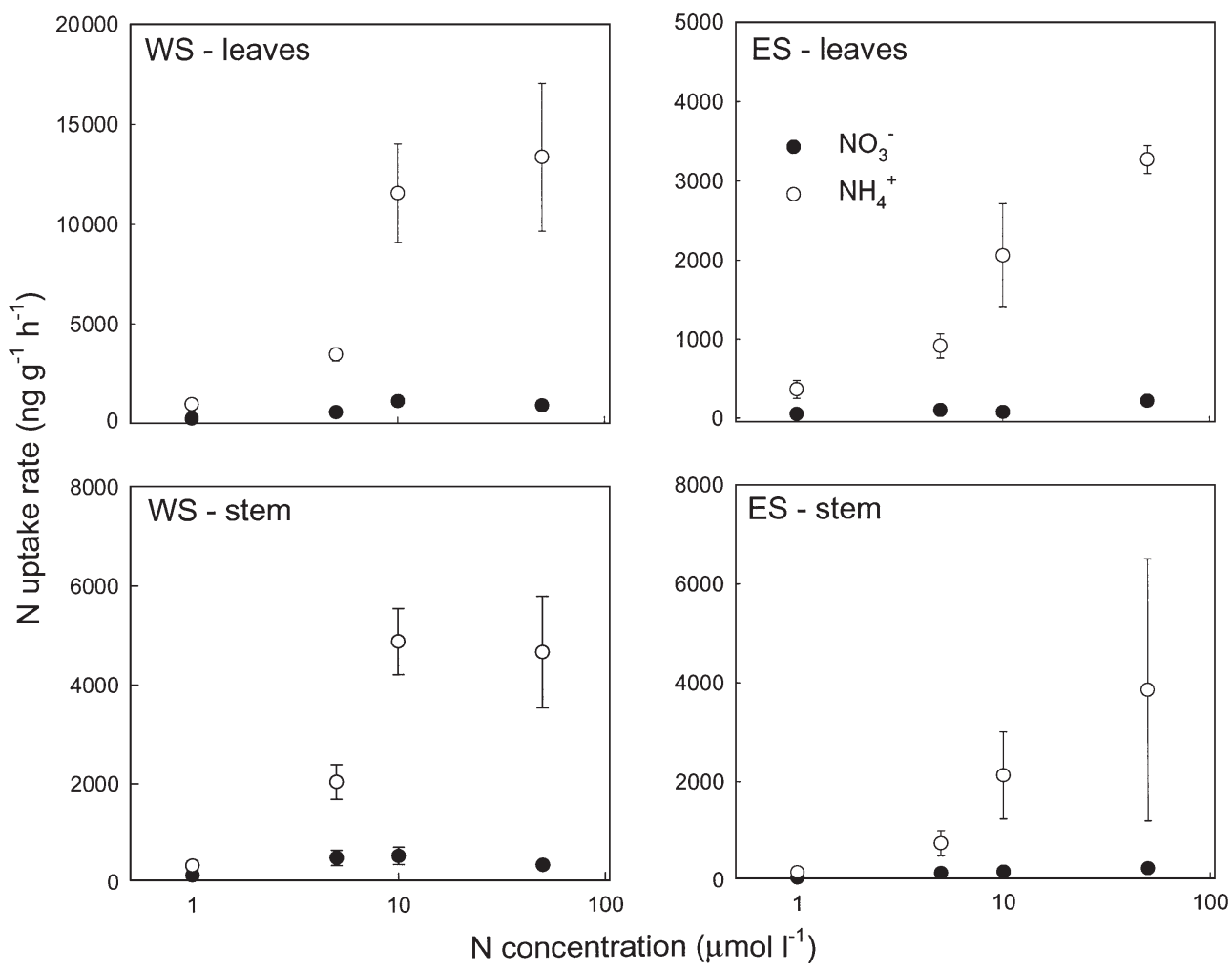

Fig. 7. Spartina anglica. Effects of $\mathrm{N}$-concentration on uptake rates (ng $[\mathrm{g} \text { dry mass }]^{-1} \mathrm{~h}^{-1}$ ) of $\mathrm{NO}_{3}{ }^{-}$and $\mathrm{NH}_{4}{ }^{+}$by intact shoots $(\mathrm{leaves}$ plus stems), from plants growing in the WS vs plants growing in the ES. ${ }^{15} \mathrm{~N}$-labeling was provided to the plants by flooding 
Table 3. Spartina anglica. Calculation of the maximum relative growth rate $\left(\mathrm{RGR}_{\max }\right.$ : $\mathrm{mg} \mathrm{g}^{-1} \mathrm{~d}^{-1}$; Eq. 4) that could be achieved under the assumptions that (a) flood water is the only N-source and (b) total shoot would on average be fully submerged for $2.4 \mathrm{~h} \mathrm{~d}^{-1}$ (cf. Fig. 8). $\mathrm{RGR}_{\max }$ was calculated for a range of $\mathrm{NO}_{3}{ }^{-}$and $\mathrm{NH}_{4}{ }^{+}$concentrations similar to those observed in the field (Fig. 1), and for which we measured the uptake rates (Fig. 7)

\begin{tabular}{|lcccc|}
\hline \multirow{2}{*}{ Parameter } & \multicolumn{2}{c}{ WS } & \multicolumn{2}{c|}{ ES } \\
& Leaves & Stem & Leaves & Stem \\
\hline $\mathrm{N}_{\text {-content }}$ & 12.5 & 7.1 & 17.5 & 9.1 \\
$\mathrm{RGR}_{\max }$ at $1 \mu \mathrm{M} \mathrm{NO}_{3}{ }^{-}$ & 0.04 & 0.04 & 0.01 & 0.01 \\
$\mathrm{RGR}_{\max }$ at $5 \mu \mathrm{M} \mathrm{O}_{3}{ }^{-}$ & 0.10 & 0.16 & 0.01 & 0.03 \\
$\mathrm{RGR}_{\max }$ at $10 \mu \mathrm{MO}_{3}{ }^{-}$ & 0.20 & 0.17 & 0.01 & 0.03 \\
$\mathrm{RGR}_{\max }$ at $50 \mu \mathrm{NO}_{3}{ }^{-}$ & 0.15 & 0.11 & 0.03 & 0.05 \\
$\mathrm{RGR}_{\max }$ at $1 \mu \mathrm{MH}_{4}{ }^{+}$ & 0.18 & 0.11 & 0.05 & 0.04 \\
$\mathrm{RGR}_{\max }$ at $5 \mu \mathrm{MH}_{4}{ }^{+}$ & 0.66 & 0.68 & 0.12 & 0.19 \\
$\mathrm{RGR}_{\max }$ at $10 \mu \mathrm{MH}_{4}{ }^{+}$ & 2.21 & 1.64 & 0.28 & 0.55 \\
$\mathrm{RGR}_{\max }$ at $50 \mathrm{M} \mathrm{NH}_{4}{ }^{+}$ & 2.55 & 1.56 & 0.45 & 1.01 \\
\hline
\end{tabular}
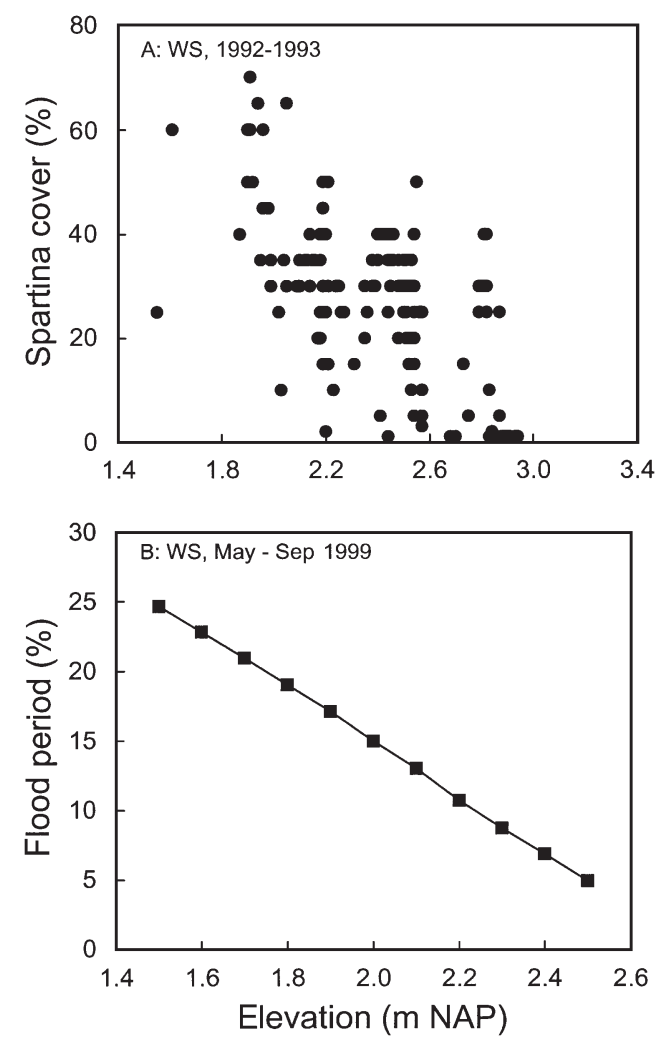

Fig. 8. Spartina anglica. Cover of (8A) and fraction of time that flooding occurs (B) as a function of elevation. Elevation is given in $m$ above the Dutch Ordnance Level (m NAP). The data on cover were obtained at the Westernschelde marsh near Waarde during 1992 and 1993. The relative flood period was derived from measurements taken at Hansweert, situated about $10 \mathrm{~km}$ east of the Waarde marsh, over the period 1 May 1999 to 30 September 1999 tation with a relatively high biomass per $\mathrm{m}^{2}$ as seen later in the growth season, N-uptake by the shoots could theoretically make a substantial contribution to the N-requirements for a linear increase in biomass (30\% max.: Table 4). However, such a substantial contribution would require, at the end of the growth season, unrealistically high $\mathrm{NH}_{4}{ }^{+}$concentrations in the flood water $\left(\geq 10 \mu \mathrm{M} \mathrm{NH}_{4}{ }^{+}\right.$for the period between June and September) and unrealistically long flood periods ( $\geq 2.4 \mathrm{~h} \mathrm{~d}^{-1}$ fully submerged). Lower $\mathrm{NH}_{4}{ }^{+}$concentrations ( $5 \mu \mathrm{M}$; Fig. 1) and shorter flood periods would, together, reduce the contribution of $\mathrm{N}$-uptake by the shoots proportionally, so that a maximum contribution of around $10 \%$ seems a more realistic estimate (Table 4). Our findings thus emphasize the importance of other N-sources for plant growth. The present results suggest that in addition to N-recycling within

Table 4. Spartina anglica. Calculation of the maximum percentage of overall N-requirements for aboveground growth that could be met by $\mathrm{NO}_{3}{ }^{-}$and $\mathrm{NH}_{4}{ }^{+}$taken up by the shoot from flood water ( $U_{\%} ; \%$ : Eq. 5). $U_{\%}$ was calculated over consecutive months, for the range of $\mathrm{NO}_{3}{ }^{-}$and $\mathrm{NH}_{4}{ }^{+}$concentrations for which we measured uptake rates (Fig. 7). Our calculation was based on the assumptions that during the growth season (1) plant biomass increases linearly over time at a rate of $6.9 \mathrm{~g} \mathrm{~m}^{-2} \mathrm{~d}^{-1}$, starting at $50 \mathrm{~g} \mathrm{~m}^{-2}$ on 1 May (cf. Fig. 2 in Groenendijk 1984), (2) total shoot would on average be fully submerged for $2.4 \mathrm{~h} \mathrm{~d}^{-1}$ (cf. Fig. 8), and (3) leaves/stem-ratio is 0.91 (average of 225 plots harvested in September 1999).

Bold-italics: values $\geq 10 \%$

\begin{tabular}{|c|c|c|c|c|}
\hline & \multicolumn{2}{|c|}{ WS } & \multicolumn{2}{|c|}{ ES } \\
\hline & $\mathrm{NO}_{3}^{-}$ & $\mathrm{NH}_{4}{ }^{+}$ & $\mathrm{NO}_{3}^{-}$ & $\mathrm{NH}_{4}^{+}$ \\
\hline \multicolumn{5}{|l|}{$1 \mu \mathrm{M} N$} \\
\hline May & 0.1 & 0.3 & 0.0 & 0.1 \\
\hline June & 0.2 & 0.8 & 0.0 & 0.2 \\
\hline July & 0.3 & 1.2 & 0.1 & 0.4 \\
\hline August & 0.5 & 1.6 & 0.1 & 0.5 \\
\hline September & 0.6 & 2.1 & 0.1 & 0.6 \\
\hline \multicolumn{5}{|l|}{$5 \mu \mathrm{M} \mathrm{N}$} \\
\hline May & 0.3 & 1.6 & 0.0 & 0.4 \\
\hline June & 0.7 & 3.6 & 0.1 & 0.9 \\
\hline July & 1.1 & 5.6 & 0.2 & 1.3 \\
\hline August & 1.5 & 7.7 & 0.2 & 1.8 \\
\hline September & 1.9 & 9.7 & 0.3 & 2.3 \\
\hline \multicolumn{5}{|l|}{$10 \mu \mathrm{M} \mathrm{N}$} \\
\hline May & 0.4 & 4.5 & 0.0 & 1.0 \\
\hline June & 1.0 & 10 & 0.1 & 2.3 \\
\hline July & 1.6 & 16 & 0.2 & 3.6 \\
\hline August & 2.1 & 22 & 0.2 & 4.9 \\
\hline September & 2.7 & 28 & 0.3 & 6.1 \\
\hline \multicolumn{5}{|l|}{$50 \mu \mathrm{M} N$} \\
\hline May & 0.3 & 4.7 & 0.1 & 1.7 \\
\hline June & 0.7 & 11 & 0.2 & 4.0 \\
\hline July & 1.1 & 17 & 0.4 & 6.2 \\
\hline August & 1.5 & 23 & 0.5 & 8.5 \\
\hline September & 1.9 & 30 & 0.6 & 11 \\
\hline
\end{tabular}


the plant, the root systems are the main source for acquiring external $N$, regardless of the strongly reduced anoxic soils that characterize the low marsh where these halophytes grow (Armstrong et al. 1985, Ewing et al. 1997). In other studies we have focussed on the root growth strategies (i.e. root architecture, root plasticity in relation to elevational height of a species habitat) that enable halophytic species to cope with such unfavorable soil conditions in the low marsh (Bouma et al. 2001a,b).

The relatively low uptake capacity of Spartina anglica leaves contrasts with the situation for rooted, submerged, aquatic plant species such as seagrasses, in which foliar uptake can contribute up to $90 \%$ of the overall N-requirement (see 'Introduction'). However, a $10 \%$ contribution of foliar $\mathrm{N}$-uptake to the overall $\mathrm{N}$-requirements for plant growth is not too different from the percentages in (e.g.) forest ecosystems (2 to $8 \%$ : Boyce et al. 1996; up to $5 \%$ : Wilson \& Tiley 1998). Similarly, as found for aquatic (Touchette \& Burkholder 2000) and terrestrial (Wilson 1992, Peuke et al. 1998, Ignatova \& Dambrine 2000) angiosperms and marine algae (Lotze \& Schramm 2000), we found that foliar uptake is generally higher for $\mathrm{NH}_{4}^{+}$than for $\mathrm{NO}_{3}{ }^{-}$. A linear increase in the uptake rate (Figs. 2 \& 3) with increasing $\mathrm{N}$-concentration has also been reported for other plant species, and possible implications of such a linear increase for the uptake mechanism have been discussed in detail by Wilson (1992).

The main question that arises is why halophytic plant species that grow in the low parts of N-limited tidal salt marshes (Valiela \& Teal 1974, Kiehl et al. 1997) do not have a higher N-uptake capacity of their leaves. There may be a trade-off between having a high uptake capacity in the leaves and living in a tidal area. If a high uptake capacity of the leaves reduces survival during low tide, it will be selected against, as plants are only flooded during a short period of the day. One adaptation of Spartina anglica in our experiments is the strong hydrophobic characteristics of the upper layer of its leaves. During flooding, the upper leaves are shielded from the water by a thin layer of air (data not shown). This air layer not only prevents water intrusion through the stomata into the leaves, but also reduces the plant's capacity for foliar N-uptake and may thus represent a trade-off against living in a frequently flooded area. No such air layer is however present around the lower leaves, which lack stomata. The low N-uptake despite the absence of a hydrophobic layer at the lower leaf level indicates that the lower leaves must have a relatively impermeable cuticle with few carriers for N-transport. Such an impermeable cuticle will help to prevent the leaves from excessive water loss during low tide and excessive leaching from (in)organic solutes during high tide.
Summarizing, even though nitrogen limits plant growth in most salt marshes, we found that foliar $\mathrm{N}$-uptake from the tidal water does not make an important contribution to Spartina anglica's N-requirement at the $\mathrm{NO}_{3}{ }^{-}$and $\mathrm{NH}_{4}{ }^{+}$concentrations present in the tidal water during its growth season. This is in contrast to the foliar uptake seen in many submerged aquatic species. Its low capacity for N-uptake is probably (at least partly) due to the hydrophobic characteristics of the upper layer of its leaves and the impermeable cuticle of the lower leaves, representing a trade-off against living in a habitat that is regularly flooded.

Acknowledgements. We thank J. Middelburg for his valuable comments and suggestions on earlier versions of the text. We gratefully acknowledge J. Nieuwenhuize, P. van Breugel, C. Kleppe and Y. Maas of the analytical laboratory for ${ }^{15} \mathrm{~N}$ analysis. We thank $\mathrm{H}$. van Hulzen for providing us with data on the leaves/stem-ratio, and we thank P. Herman and T. IJsebaert for their help with the statistical analysis. This is publication 2934 of the NIOO-KNAW Centre for Estuarine and Coastal Ecology, Yerseke, The Netherlands.

\section{LITERATURE CITED}

Armstrong W, Wright EJ, Lythe S, Gaynard JT (1985) Plant zonation and the effects of spring neap tidal cycle on soil aeration in a Humber salt marsh. J Ecol 73:323-339

Armstrong W, Beckett PM, Justin SHF, Lythe S (1991) Modeling and other aspects of root aeration. In: Jackson MB, Davies DD, Lambers $\mathrm{H}$ (eds) Plant life under oxygen stress. SPB Academic Publishing, The Hague, p 267-282

Bouma TJ, Koutstaal B, van Dongen M, Nielsen KL (2001a) Coping with low nutrient availability and inundation: root growth responses of three halophytic grass species from different elevations along a flooding gradient. Oecologia 126:472-481

Bouma TJ, Nielsen KL, van Hal J, Koutstaal B (2001b) Root system topology and diameter distribution of species from habitats differing in inundation frequency. Funct Ecol 15: 360-369

Boyce RL, Friedland AJ, Chamberlain CP, Poulson SR (1996) Direct canopy nitrogen uptake from ${ }^{15} \mathrm{~N}$-labeled wet deposition by matured spruce. Can J For Res 26:1539-1547

Broome SW, Seneca ED, Woodhouse WW (1983) The effect of source, rate and placement of nitrogen and phosphorus fertilizers on growth of Spartina alterniflora transplants in North Carolina. Estuaries 6:212-226

Brumme R, Leimcke U, Matzner E (1992) Interception and uptake of $\mathrm{NH}_{4}{ }^{+}$and $\mathrm{NO}_{3}{ }^{-}$from wet deposition by aboveground parts of young beech (Fagus sylvatica L.) trees. Plant Soil 142:273-305

de Leeuw J, Apon LP, Herman PMJ, de Munck W, Beeftink WG (1994) The response of salt-marsh vegetation to tidal reduction caused by the Oosterschelde storm-surge barrier. Hydrobiologia 283:335-353

Ewing K, McKee KL, Mendelssohn IA (1997) A field comparison of indicators of sublethal stress in the salt-marsh grass Spartina patens. Estuaries 20:48-65

Groenendijk AM (1984) Primary production of 4 dominant salt-marsh angiosperms in the SW Netherlands. Vegetatio $57: 143-152$ 
Ignatova N, Dambrine E (2000) Canopy uptake of N deposition in spruce (Picea abies L. Karst) stands. Ann For Sci 57: $113-120$

Iizumi H, Hattori A (1982) Growth and organic production of eelgrass (Zostera marina L.) in temperate waters of the pacific coast of Japan. III. The kinetics of nitrogen uptake. Aquat Bot 12:245-256

Kiehl K, Esselink P, Bakker JP (1997) Nutrient limitation and plant species composition in temperate salt marshes. Oecologia 111:325-330

Lea-Cox JD, Syvertsen JP (1995) Nitrogen uptake by citrus leaves. J Am Soc Hortic Sci 120:505-509

Lee KS, Dunton KH (1999) Inorganic nitrogen acquisition in the seagrass Thallassia testudinum: development of a whole-plant nitrogen budget. Limnol Oceanogr 44:53-63

Lotze HK, Schramm W (2000) Ecophysiological traits explain species dominance patterns in macroalgal blooms. J Phycol 36:287-295

Marschner H (1995) Mineral nutrition of higher plants, 2nd edn. Academic Press, London

Mendelssohn IA (1979) The influence of nitrogen level, form and application method on the growth response of Spartina alterniflora in North Carolina. Estuaries 2:106-112

Patrick WH Jr, Delaune RD (1976) Nitrogen and phosphorus utilization by Spartina alterniflora in a salt marsh in Barataria Bay, Louisiana. Estuar Coast Mar Sci 4:59-64

Pearson J, Stewardt GR (1993) The deposition of atmospheric ammonia and its effects on plants. New Phytol 125: 283-305

Pedersen MF, Borum J (1992) Nitrogen dynamics of eelgrass Zostera marina during late summer periods of high growth and low nutrient availability. Mar Ecol Prog Ser 80:65-73

Pedersen MF, Borum J (1993) An annual nitrogen budget for a seagrass Zostera marina population. Mar Ecol Prog Ser 101:169-177

Peuke AD, Jeschke WD, Dietz KJ, Schreiber L, Hartung W (1998) Foliar application of nitrate or ammonium as sole nitrogen supply in Ricinus communis. I. Carbon and nitrogen uptake and inflows. New Phytol 138:675-687

Editorial responsibility: Otto Kinne (Editor),

Oldendorf/Luhe, Germany
Poorter H, Remkes C (1990) Leaf area ratio and net assimilation rate of 24 wild species differing in relative growth rate. Oecologia 83:553-559

Poorter H, van der Werf A, Atkin OK, Lambers H (1991) Respiratory energy requirements of roots vary with the potential growth rate of plant species. Physiol Plant 83:469-475

Reickenberg RL, Pritts MP (1996) Dynamics of nutrient uptake from foliar fertilizer in red raspberry (Rubus idaeus L.). J Am Soc Hortic Sci 121:158-163

Short FT, McRoy CP (1984) Nitrogen uptake by leaves and roots of the seagrass Zostera marina L. Bot Mar 27: $547-555$

Stapel J, Aarts TL, van Duynhoven BHM, de Groot JD, van de Hoogen PHW, Hemminga MA (1996) Nutrient uptake by leaves and roots of the seagrass Thalassia hemprichii in the Spermonde Archipelago, Indonesia. Mar Ecol Prog Ser 134:195-201

Terrados J, Williams SL (1997) Leaf versus root nitrogen uptake by the surfgrass Phyllospadix torreyi. Mar Ecol Prog Ser 149:267-277

Touchette BW, Burkholder JM (2000) Review of nitrogen and phosphorus metablism in seagrasses. J Exp Mar Biol Ecol 250:133-167

Umar S, Bansal SK, Imas P, Magen H (1999) Effect of foliar fertilization of potassium on yield, quality and nutrient uptake of groundnut. J Plant Nutr 22:1785-1795

Valiela I, Teal JM (1974) Nutrient limitation in salt marsh vegetation. In: Reimold RJ, Queen WH (eds) Ecology of halophytes. Academic Press, New York, p 547-563

Wilson EJ (1992) Foliar uptake and release of inorganic nitrogen compounds in Pinus sylvestris L. and Picea abies (L.) Karst. New Phytol 120:407-416

Wilson EJ, Tiley C (1998) Foliar uptake of wet-deposited nitrogen by Norway spruce: an experiment using ${ }^{15} \mathrm{~N}$. Atmos Environ 32:513-518

Wright AL, Weaver RW, Webb JW (1996) Concentrations of N and $\mathrm{P}$ in floodwater and uptake of ${ }^{15} \mathrm{~N}$ by Spartina alterniflora in oil-contaminated mesocosms. Bioresour Technol $56: 257-264$

Submitted: October 25, 2001; Accepted: May 17, 2002

Proofs received from author(s): August 22, 2002 